\title{
Study of Civic Disposition Based on The Way of Life of Kuta Traditional Society in Keeping The Balance of Nature
}

\author{
Trisna Sukmayadi*, Supriyadi Supriyadi \\ Department of Pancasila and Civic Education, Faculty of Teacher Training and Education \\ Ahmad Dahlan University \\ Yogyakarta, Indonesia \\ *trisnasukmayadi@ppkn.uad.ac.id
}

\begin{abstract}
Indonesian citizens who are multicultural have various local wisdoms. Local wisdom becomes a strength to build the character of nation and civilization. One of local wisdom which is kept until now is the way of life of Kuta traditional society in keeping the balance of nature. This study aims to reveal the way of life of Kuta traditional society in keeping the balance of nature so that they can live with nature. It uses qualitative approach which type is case study. The methods of data collection used are literature review, interviews, observation, and documentation. The result of this study indicates : (1) the Kuta traditional society orients to a proverb which says, "plant trees in mountain, plant bamboos in slope of mountain, make valley as pond, and make flat ground as house", in order to avoid the forest damage, water well damage, and human misery; (2) the way of life is implemented in building a house, cultivating, and keeping the forest well; (3) the way of live is inherited by oral tradition and good figure of Kuta villagers.
\end{abstract}

Keywords-local wisdom; civic disposition; way of life

\section{INTRODUCTION}

Forest as one of area supporting human life needs to be kept and managed well. Indonesia is a country which has very wide forests. Based on the data of WWF Indonesia, it indicates that the tropical forest in Indonesia is the home and last hiding place for world biodiversity which is unique. The biodiversity which is in Indonesian forest consists of $12 \%$ of mammal species in the world, 7,3\% of the reptile and amphibian species in the world, and $17 \%$ of bird species in the world. Based on the data of FAO in 2010 which discusses about the world forest, including Indonesian forest, it saves 289 gigaton of carbon which has an important role in keeping the stability of world climate. The forest damage is caused by human who cannot keep and protect the forest well, for instance illegal logging, land transport and forest fire. The impacts of forest damage are flood and landslide which certainly takes advantages for human. It does not only affect a financial loss, but it also affects an inhabitant loss [1-2].

West Java province is a region which has wide forest, but it also has big forest damage. According to Dadan Ramdan, the director of WALHI, West Java, the forest which is the life support and nature service in West Java is in a critical condition [3]. It occurs, because West Java has only 18,2\% forest area of West Java area which is around 4,4 million hectares. Based on the law of Indonesia no. 26, 2017 about area management, the forest must be $30 \%$ of the total area. It means that West Java province has little forest which function as forest. This condition takes negative impact significantly, such as flood and land slide occurring recently which worry each person.

The sacred forest or leuweung gede which is around 40 hectares is one of forest in West Java, exactly located in Kuta village, Ciamis regency still functioning as a forest. The forest is kept and protected traditionally by the Kuta traditional society. In 2002, it achieves Adipura nomination from the government.

Based on the explanation in paragraph $1-4$, there is a dominant factor why the forest is damaged and why the forest is long-lasting. It is the human. Human who does not have good values certainly damages the forest by various way, but human who has good values certainly keeps and protects the forest. It is shown by the Kuta traditional society managing the sacred forest.

The Kuta traditional society managing the sacred forest orient to keep the balance of nature. They believe that the balance of nature has to be kept in order to take benefit for human. Human is the prime factor in keeping the forest. Thus the management of sacred forest is conducted traditionally.

The Kuta traditional society thinks that managing the sacred forest is one of reinforcements in developing the civic disposition. According to KBBI, disposition means a human inner character affecting the whole mind and attitude. Way of life means a concept gained by an individual or group in social life which aims to respond and explain all problems in this world. Thus people having a strong way of life certainly have a strong civic disposition.

\section{THEORETICAL REVIEW}

\section{A. Review of Local Wisdom}

There are some definitions of local wisdom which is complementary each other. In anthropology, local wisdom is well-known as local genius. Local genius is cultural identity 
which makes a nation be able to absorb and process foreign cultures based on the disposition and ability. Local wisdom is the human creation and mind which thereupon becomes a guidance for group identity and attitude and nation identity [4]. Generally, local wisdom can be defined as local opinions which are wise and good, and they are implemented and followed by the members [5]. Local wisdom has glorious values applied in social life system to keep and manage the environment well because the process of interaction between human and environment in fulfilling needs [6-7]. Based on the definition above, there are some components in constructing local wisdom.

- The people's opinions has good values

- it is applied in a place and society

- There is an interaction between the human and environment balanced

- It is one of nation identity

Indonesia is a multicultural country which has various local wisdoms. Multicultural society is a society consisting of race, tribe, culture, religion language, etc. Local wisdom is formed in each social unit or society. It is either tribe or other community. Local wisdom is the output of culture which is a local policy related to goodness toward environment. One of them is managing the forest traditionally. Thus the local wisdom in each region is different. The protection and management of environment is conducted based on the principle of local wisdom. The principle of local wisdom means that in protecting and managing the environment, it needs to understand the glorious values applied in social life system.

The success of local wisdom surely depends on the society. Thus exploring local wisdom values is really needed. It aims to make the next generations know their local wisdom in their region. A strong local wisdom will build a strong character, so that it can be an identity of nation which is different from other countries.

\section{B. The Review of Traditional Society}

The extension of traditional society becomes an interesting topic, because one of societies still keeps the belief inherited by the ancestor. Now we can call it local wisdom.

Traditional society in KBBI is known as a society having old traditions. According to the alliance of indigenous people of the archipelago in the first congress in 1999 distributed by Wikipedia, it is a community living in a place which is inherited from the ancestor which has sovereignty toward the wealth of nature, and the social life is regulated by customary law and organization regulating the social life.

Traditional society of all regions in the archipelago has various characteristics. A half of them have a sophisticated organization mechanism and the rest of them have a simple mechanism. The traditional society is a traditional society developing local organization mechanism which is feudal, and is dominated by men. There is also a traditional society having egality character, where woman takes a part in choosing decision. Each group has various dynamics which history is different. They live in various places, such as in mountain, valley, savannah, coast, and Small Island. In each region, the society has a system and land authority which is dynamic and is influenced by the development of nature, ecosystem, social factors, economy, and politic.

The traditional society has a right which is different from other society. There are 6 rights owned by the traditional society.

- The traditional society runs its administration by itself

- It takes over and manage the natural resources in its region for the citizens

- It acts to manage and take care of the citizens and environment

- It has a right to take a part in each transaction related to its environment and it acts on the behalf of association as law corporation

- It has a right to make a custom

- It has a right to have judicature

Based on those rights the traditional society has more special thing than other society. It occurs because the traditional society has a little scope but it has a special thing. Traditional society holds its belief, especially in culture which is inherited from the ancestor to the next generation. That is what is applied by the Kuta traditional society.

\section{Review of Managing Forest Traditionally}

One of the local wisdom forms shown by the traditional society is making forest as a sacred place. Forest is kept by sharing various taboos functioning to control human activities in that place. Obedience toward taboo is inherited from the ancestor to the next generation in order to make forest well. Glorious value which can be gained from traditional society is local wisdom in managing environment, including forest. It is an important value possessed by traditional society which is related to exploration and exploitation of nature. The cultural value is regard as the most effective method in keeping the nature.

According to KBBI, the concept of traditional forest management consists of 3 words, namely management, forest, and tradition. Management means supervising all related to policy and achievement. Forest means plants growing on the wide land. Tradition means something which has been a custom. Thus the traditional forest management can be defined as the process of surveillance conducted by society toward land and plants on the land based on the tradition inherited from the ancestors.

The regulation about traditional forest management is written in law of the republic of Indonesia no. 41, 1999 about forestry. Then it changes to law of the republic of Indonesia no. 19,2004 . In article 67 verse 1 , it tells that traditional society still exist and is admitted. Then it may do some activities.

- The traditional society may exploit the forest resources to fulfill the daily need 
- The traditional society manage the forest based on the law applied and does not contrast to law of the republic of Indonesia

- The traditional society has a right to get empowerment in order to be prosperous

Those basically gives freedom to the traditional society to manage forest traditionally based the tradition inherited from the ancestor.

The traditional society has an important role in managing the forest and function forest normally. There are 6 important roles [8].

- The traditional society has a high motivation and get an incentive which is valuable to protect forest, because it is related to the existence of the traditional society.

- The traditional society has an original knowledge in keeping and exploiting the forest resources in its habitat.

- The traditional society has a law to apply.

- The traditional society has a customary organization which manages the harmonious interaction toward ecosystem.

- A half of the traditional society has already had an organization and job network to build a solidarity among the traditional society organizations and organize the politic and technical support from other party.

- The traditional society is protected by law of the Republic of Indonesia and is arranged in some international instruments which explain that the country must recognize, respect and protect the tradition rights.

Based on the explanation about the importance of the traditional society in managing the forest, there are two important things which are only possessed by the traditional society. The first one is the traditional society having an original knowledge inherited by the ancestor. The second one is the traditional society having authority to make its own law to get benefit.

\section{METHOD}

This uses qualitative approach which type is case study. Something special in it is the Kuta traditional society, Ciamis regency, West Java province which has a special way in managing the sacred forest which still exists until now. The success of forest management traditionally makes the Kuta traditional society get Adipura nomination in 2002.

The data are collected in 4 ways. The first one is doing literature review toward references related to forest management traditionally. The second one is interviewing the caretaker of sacred forest and the chairman of Kuta village using purposive and snowball technique. The third one is observing the situation and condition of the sacred forest in Kuta village. The fourth is documenting the documents related to the sacred forest management traditionally.
This study is designed in 4 phases. The first one is approaching the caretaker of the sacred forest and the chairman of Kuta village. The second one is exploring by interviewing, observing, and documenting something related to local wisdom values in keeping the sacred forest in Kuta village. The third one is adding checklist to each caretaker of sacred forest, which aims to get high credibility, transferability, dependability, and confirm ability. The fourth one is analyzing the qualitative data based on Miles and Huberman model which consists of three activities, namely data reduction, data display, and conclusion or verification.

Finally, complete content and organizational editing before formatting. Please take note of the following items when proofreading spelling and grammar:

\section{RESULT AND DISCUSSION}

\section{A. Result}

The Kuta traditional society has some ways of life in managing the forest, namely (a) way of life in prohibition; (b) way of life in managing the nature, namely gunung kayuan (plant trees in mountain), lamping awian (plant bamboos in slope of mountain), legok balongan (make valley as pond), datar imahan (make flat ground as house), pasir talunan (make hill as fruit garden), lebak caian (irrigate the water to the valley), and sampalan kebonan (make yard as garden); (c) way of life in keeping the nature, namely cinyusu rumatan (keep water well), walungan rawatan (keep river), daratan sawahan (make land as rice field), situ pulasaraeun (keep lake), lembur uruseun (manage village), and basisir jagaeun (keep coast); (d) those ways of life are still kept and applied until now and there are three consequences of not applying the way of life, namely leuweung ruksak (forest damage), cai beak (water depletion), and manusa balangsak (human misery). Those are applied in building a house, cultivating, and keeping the forest, and is inherited to the next generation of Kuta villagers.

\section{B. Discussion}

1) Analysis based on values in the cultural education and nation disposition

One of efforts to construct the nation disposition and civilization is applying cultural education and character building which functions as a betterment, improvement, and filter for the culture and character, so that it can prevent the future problem which is more complicated, such as less of attention and sympathy toward environment, irresponsibility, less of self-confidence, etc.

There are 18 values which ought to be developed to strengthen the cultural education and nation character, namely religious, honest, tolerant, disciplinal, hard-working, creative, independent, democratic, curious, nationalistic, patriotic, read a holic, environmental care, social care, and responsible. Based on those values, there are three prime local wisdom values in way of life of Kuta traditional society in managing the sacred forest. 
TABLE I. LOCAL WISDOM VALUES BASED ON THE WAY OF LIFE IN MANAGING FOREST

\begin{tabular}{|c|c|c|c|}
\hline No & Way of Life & Local Wisdom Values & $\begin{array}{c}\text { Character } \\
\text { Values }\end{array}$ \\
\hline 1 & Prohibiting & Pamali (taboo) & Religious \\
\hline 2 & $\begin{array}{l}\text { Nature } \\
\text { management }\end{array}$ & $\begin{array}{l}\text { gunung kayuan (plant trees in } \\
\text { mountain) } \\
\text { lamping awian (plant bamboos in } \\
\text { slope of mountain) } \\
\text { legok balongan (make valley as } \\
\text { pond) } \\
\text { datar imahan (make flat ground } \\
\text { as house) } \\
\text { pasir talunan (make hill as fruit } \\
\text { garden) } \\
\text { lebak caian (irrigate the water to } \\
\text { the valley) } \\
\text { sampalan kebonan (make yard as } \\
\text { garden) }\end{array}$ & Discipline \\
\hline 3 & $\begin{array}{l}\text { Nature } \\
\text { protection }\end{array}$ & $\begin{array}{l}\text { cinyusu rumatan (keep water } \\
\text { well) } \\
\text { walungan rawatan (keep river) } \\
\text { daratan sawahan (make land as } \\
\text { rice field) } \\
\text { situ pulasaraeun (keep lake) } \\
\text { lembur uruseun (manage village) } \\
\text { basisir jagaeun (keep coast) }\end{array}$ & $\begin{array}{l}\text { Enviromental } \\
\text { care }\end{array}$ \\
\hline 4 & Impact & $\begin{array}{l}\text { leuweung ruksak (forest damage) } \\
\text { cai beak (water depletion) } \\
\text { manusa balangsak (human } \\
\text { misery) }\end{array}$ & Religious \\
\hline
\end{tabular}

Based on the table 4.2.1, after interview and observation, the central value is the religious value from the concept of pamali (taboo). Pamali (taboo) is one of half oral folklores believed by the traditional society. A half of societies believe that pamali (taboo) is a prohibition and other societies believe that it is a myth or the heritage of ancestors. Pamali (taboo) is a prohibition. If it is not obeyed, there will be an accident. Also pamali (taboo) has a role as the rule of society, especially in Sunda. It organizes the lifestyle of traditional society out of religion [9]. Pamali (taboo) cannot be identified the origin. It is absolutely possessed by tribes of Indonesia. For Sudanese's, pamali (taboo) becomes their regulation which is full of prohibition that they hold the regulation in pamali (taboo).

Pamali (taboo) is basically a prohibition without questions. It means that if the believers of pamali (taboo) are prohibited to do something, they will not ask the reason. It happens because they believe that when they disobey pamali (taboo) they will get an accident unexpectedly. The Kuta traditional society really keeps the pamali (taboo) in each utterance and action. One of pamali (taboos) is keeping the sacred forest in Kuta village. Nobody may wear slippers. The Kuta traditional society believes if all people obey it, God Almighty and ancestors' soul will make them fortune in each their life.

\section{2) Analysis based on theory of symbolic interactionism}

The process of value acceptance is related to the roles of symbol. The way of life of Kuta traditional society is one of symbols communicated every day. The symbols thereupon forms a pattern that each person will obey it directly or indirectly. The assumption as source and basis of interactionism symbolic consists of three activities, namely (1) exchanging the symbols which have relation one another, (2) self-formed by communication, (3) social activities by one's process of role removal. The process of role removal is conducted by the old person who is called Kuncen Leuwung Gede.

There are 4 stages in process of interactionism symbolic of Kuta traditional society.

- Impulse, in this stage, the Kuta traditional society still keep its way of life because of physical or non-physical needs. Physical needs mean the Kuta traditional society needs its natural resource well. The nonphysical needs mean the Kuta traditional society needs blessing from God Almighty and ancestor's soul in every activity.

- Perception, in this stage, the Kuta traditional society has think that both physical and non-physical needs are the prime needs, because they are inherited from the ancestors to the next generation and are kept. One of the heritages is the way of life in keeping the nature.

- Manipulation, in this stage, the Kuta traditional society applies the heritages of the ancestors. Those are the implementations of way of life in keeping the balance of nature.

- Conclusion, in this, the Kuta traditional society tries to implement the way of life that it will avoid them from something contrasting to the law applied by the ancestors.

Based on the stage of interactionism symbolic above, what is conducted by the Kuta traditional society is the implementations of symbols inherited from the ancestors to the next generation which is kept and still applied. Thus it inherit by oral tradition with symbols.

3) Analysis based on system of way of life value

According to KBBI system is components having relation one another that it creates a totality. Thus it is a unity of different component and has different function but it has the same goal. If one function is disturbed, it will impact to other functions.

System of value based on the way of life of Kuta traditional society in keeping the balance of nature consists of two ways and impact which are systematic and hierarchical. It is called systematic because it is a unity and is called hierarchical because it may not precede the method 1, 2, and 3 . The first method is managing the environment. Because all people believe if the nature is arranged well, the way to keep nature will be easy. The second method is keeping. Keeping means implementing the way of life traditionally that the nature will give benefits for the Kuta traditional society. The impact of managing and keeping is expected to take benefits the Kuta traditional society life. 


\begin{tabular}{|c|c|c|}
\hline $\begin{array}{l}\text { Nature protection: } \\
\text { a. Gumung kayuan (mountain } \\
\text { wooden plant) } \\
\text { b. lamping awian (bamboo } \\
\text { planting cliffs) } \\
\text { c. Legok balongan (valleys } \\
\text { made ponds) } \\
\text { d. Datar imahan (plains built } \\
\text { homes) } \\
\text { e. Pasir talunan (hill made } \\
\text { talun) } \\
\text { f. Lebak caian (the valley is } \\
\text { watered) } \\
\text { g. Sampalan kebonan (tegal } \\
\text { made garden) }\end{array}$ & $\begin{array}{l}\text { Nature protection: } \\
\text { a. cinyusu rumatan (keep } \\
\text { water well) } \\
\text { b. walungan rawatan (keep } \\
\text { river) } \\
\text { c. daratan sawahan (make } \\
\text { land as rice field) } \\
\text { d. situ pulasaraeun (keep lake) } \\
\text { e. lembur uruseun (manage } \\
\text { village) } \\
\text { f. basisir jagaeun (keep coast) }\end{array}$ & $\begin{array}{l}\text { Impact: } \\
\text { a. leuweung ruksak (forest } \\
\text { damage) } \\
\text { b. cai beak (water depletion) } \\
\text { c. mamusa balangsak (human } \\
\text { misery) }\end{array}$ \\
\hline
\end{tabular}

Fig. 1. System of the way of life of Kuta traditional society.

\section{CONCLUSION}

- The Kuta traditional society have orient to keep the balance of nature and manage forest traditionally. The way of life is reflected in forest management and protection that it does not take bad impact for Kuta traditional society. The way of life in managing nature consists of seven ways, namely gunung kayuan (plant trees in mountain), lamping awian (plant bamboos in slope of mountain), legok balongan (make valley as pond), datar imahan (make flat ground as house), pasir talunan (make hill as fruit garden), lebak caian (irrigate the water to the valley), and sampalan kebonan (make yard as garden). The way of life in keeping the nature consists of 6 ways, namely cinyusu rumatan (keep water well), walungan rawatan (keep river), daratan sawahan (make land as rice field), situ pulasaraeun (keep lake), lembur uruseun (manage village), and basisir jagaeun (keep coast). There are three consequences of not applying the way of life, namely leuweung ruksak (forest damage), cai beak (water depletion), and manusa balangsak (human misery).

- The way of life of Kuta traditional society are based on the values developed in cultural education and nation's character which consists of 3 main values, namely religious, discipline, and environmental care value.

- The way of live is inherited by oral tradition.

\section{REFERENCES}

[1] Irwanto, "Kerusakan Hutan di Indonesia", Retrieved from https://www.irwantoshut.com/kerusakan_hutan_indonesia.html, Accesed 14 Januari 2017, 2012.

[2] P.B. Shanjaya, "Kerusakan Hutan Indonesia Semakin Parah", Retrieved from http://www.kompasiana.com/phungky/ kerusakan-hutan-indonesiasemakin-parah_55283223f17e6164218b46b2. Accesed 14 Januari 2017, 2013.

[3] F.A. Mukminin, "Jawa Barat Terancam Bencana Ekologis", Retrieved from http://www.tribunnews.com/regional/ 2011/06/06/jawa-baratterancam-bencana-ekologis, Accesed 14 Januari 2017, 2011.

[4] Ayatrohaedi, Kepribadian Budaya Bangsa (local Genius), Jakarta: Pustaka Jaya, 1986.

[5] Sartini, "Menggali kearifan lokal nusantara: sebuah kajian filsafati", Jurnal Filsafat, vol. 37, no. 2, Yogyakarta: UGM, Agustus 2004.

[6] I. Hilman, "Kearifan Lokal Masyarakat Hukum Adat Kampung Kuta dalam Melindungi dan Mengelola Lingkungan Hidup”, In Internasional Budaya Sunda II Conference, Revitalisasi Budaya Sunda: Peluang dan Tantangan dalam Dunia Global, Bandung: Yayasan Kebudayaan Rancage, 19-22 Desember 2011.

[7] F.F. Qandhi, Pentingnya Kearifan Lokal Masyarakat Dalam Pengelolaan Sumberdaya Alam dan lingkungan Di Pedesaan, Retrieved from https://fikafatiaqandhi.wordpress.com/2012/05/07/pentingnya-kearifanlokal-masyarakat-dalam-pengelolaan-sumberdaya-alam-dan-lingkungandi-pedesaan/. Accesed 04 Februari 2018, 2015.

[8] Aminah, "Pengelolaan Hutan Berbasis Masyarakat (PHBM) sebagai Upaya Pengakuan Hak Masyarakat Adat”, Jurnal Hukum, vol.6, No.1. Januari 2011.

[9] H. Widiastuti, "Pamali Dalam Kehidupan Masyarakat Kecamatan Cigugur Kabupaten Kuningan (Kajian Semiotik dan Etnopedagogi)", Jurnal Lokabasa, Vol. 6, No. 1, April 2015. 